\title{
The Influence of Business records on Business Performance
}

\section{C.J. Mairura}

\begin{abstract}
The necessity of recording all the transactions and systematically cannot be overemphasized. Goods may be sold on credit to several persons. The latter will pay the price of the goods to the vender latter. However, strong one's memory may be, one cannot hope to remember all the details regarding all these transactions. Besides, according to several authorities, accounting records are useful in several ways.

Despite this importance of accounting records, most small enterprises do not maintain proper accounting records moreover the influence of accounting records on business performance has not been well documented.

This study was therefore conducted with a view to establishing the role played by accounting records on business performance.

Data was collected among eighty entrepreneurs in the garments industry in Nairobi. Results indicated that there exists a positive relationship between accounting records and business performance. The analysis showed that education, nature of business ownership, training and size of business are the main factors influencing accounting record. Keeping and information for planning making are also extracted from these records. It is recommended that entrepreneurs should be trained in record keeping to enhance the performance of their business.
\end{abstract}

Key words: business records, business performance, influence.

\section{Introduction}

Since the prospects of getting white collar jobs is becoming harder and harder, many people, educated and non- educated, are reverting to being self-employed. One way of self- employment is to start a small business or what is popularly known as Jua Kali business in the Kenyan context. Entrepreneurship is too often cited as a solution to all kinds of economic problems and social ailments in many parts of the world.

A small business is any business that is independently owned and operated and is not dominant in its field of operation Kuehl (1990). However, in the Kenya development plan, GOK (1989-93, 92) it is stated that a small business is a company with less than 50 employees and has an annual turnover of up to five million shillings. It goes further to state that these small scale businesses are characterized by:ease of entry and exit, low capital requirement for establishment, dependence on local resources and recycled wastes, family ownership, labour-intensive production technologies, low cost skill acquisition mainly outside formal schooling and ability to operate under highly competitive market conditions. 


\section{Textile Industry}

Kenya's textile industry is one of the most important industries. The industry has self-employment potential. The industry needs to receive support from the government because it has potential to absorb large numbers of unskilled and semi-skilled labour, hence, can stem the ever-rising level of unemployment.

Small scale enterprises play a major role in the Kenyan economy. They contribute to the economy in terms of output of goods and services, create demand and supply for their product, contribute to increased participation of indigenous Kenyans in the economic activities of the country, strengthen forward and backward linkages among socially, economically and geographically diverse sectors of the economy, offer opportunities for entrepreneurial and managerial talents to mature and create jobs at low capital cost, especially the fast growing service sector GOK (1992).

\section{Accounting}

According to several authors (Kibuka,1996; Miles,1995; Maalu,1990), accounting as a record keeping process has evolved over many centuries to serve the social and economic needs of society. As early as 3600 B.C., clay tablets were used in the Babylonian empire to record various facts. Many of these records contained lists of events as they occurred or lists of goods belonging to an individual, estate or temple. Similar types of activities of records have also been discovered describing business activities in ancient Greece, Egypt and Rome. While these early records contained mostly inventories of goods and debts, later records began to reflect a concern for computing profit and loss from different ventures.

Modern-day accounting has its origin in the double-entry book-keeping method developed by Italian merchants during the twelfth and thirteenth centuries. The first complete description of the double entry system was included in a book called Suninia de Arithmetic, Geometria, Proportioni et and Proportionalita, published in 1494 by a Franciscan monk named Luca Pacioli (Mascove \& Simicin, 1983)).

\section{Problem statement}

The necessity of recording all the transactions clearly and systematically cannot be over-emphasized. Goods may be sold on credit to several persons. The latter would pay the price of the goods to vendor later. However strong one's memory may be, one cannot hope to remember all the details regarding the transactions. Besides, according to several authorities (Kibuka,1996; Miles,1995; Maalu,1990) accounting records are useful in the following ways; to know how good or bad the financial condition of business is, to know whether the business activity resulted in profit or loss.

Increased volume of business results in large number of transactions, and no businessman can remember everything. Accounting records obviate the necessity of remembering various transactions.

Accounting records, prepared on the basis of uniform practices will enable business to compare results of one period with another period. Taxation authority (both income tax and VAT) are likely to believe the facts contained in the set of accounting records/books if maintained according to generally accepted accounting principles. 
Accounting records backed up by proper authenticated vouchers are good evidence in court of law in the event of fraud by the customers, suppliers and employees. If a business is to be sold as a going concern then the values of different assets as shown by the balance sheet helps in bargaining proper price for the business. Also, when admitting a partner to share ownership of the business, or applying for loans or bank overdraft, the book of accounts shall be required to ascertain its value and how the business is performing.

There are many participants in the textile business. They include large manufacturers, dealers in second hand-clothes and small enterprises. The sector is highly competitive, therefore, inefficiency in management will cause failure of small enterprises. Management inefficiency in small enterprises is caused by lack of adequate information system, which is vital for decision making. The results of Gichira's (1987), study on small business disclosed that about $60 \%$ of small businesses fail within the first three years. They attributed this to management inefficiencies brought about by poor record keeping as the major cause for these failures. Cromie (1991) lists possible causes of business failure as lack of accounting, marketing, and finance among others.

Accounting is necessary for small business owners in order to understand how money is used in the business (Miles,1995). An adequate financial record-keeping-system will provide the required information to assist the business owners to make sound decisions for future plans. Banks can only lend money for working capital or for purchase of assets when they have clear evidence that the firms' cash flow can meet principal and interest payments. Most small enterprise owners do not maintain accounting records yet they perceive the positive role of accounting records in the business performance. The records are tools to measure profitability, growth and liquidity. Several research studies have been done on the factors contributing to either the success or failure of small scale enterprises. However, the main factors which most scholars ((Kibuka,1996; Miles,1995; Maalu,1990)) have identified are, finance, management, experience, marketing and accounting records.

Although accounting records have been cited as one of the possible factors contributing to success of business, there is no research done to establish how accounting influences performance. Little information if any is available on the relationship between accounting records and business performance.

In his research on the factors influencing record keeping in small enterprises, Maalu (1990) suggested that further research should be done on the relationship between accounting records and the performance of the entrepreneurs. This suggestion is the genesis of the current study.

\section{Objectives}

The main objective of the study was to establish the relationship between the maintenance of accounting records and business performance.

\section{Specific objectives}

The objectives of the study were to get the profile of entrepreneurs in business so as:

i) To establish the quality of accounting records maintained by small enterprises. 
ii) To establish factors that influenced record keeping in business.

iii)To determine the type of information extracted from the accounting records.

iv) To relate the accounting records to the business performance by comparing the small enterprises which maintained the accounting records against those which did not.

\section{Limitations}

(i) Generally, most small business owners who were interviewed believed that the researcher could benefit from the information sought from them; therefore, they also expect some benefits. This may have influenced their responses.

(ii) Most entrepreneurs decline to produce their accounting records for fear that the researcher could be operating on behalf of Kenya Revenue Authority (K. R A.) and, therefore, may be trying to unearth their financial information which they prefer keeping secret. However, the researcher gave proper identification although the figures given might have been understated in fear of high taxation penalties in case they leaked to Tax authorities.

(iii) The assumption of the study was that other factors which adversely influence business performance were held constant. It was assumed that the factors were equally affecting those businesses with or without account records.

(iv) The results of this study can be replicated in textile businesses, even though a small sample of the target population was studied, due to financial and temporal constraints.

\section{The Garment sub-sector}

According to GOK (1998) report, the textile industry has been in existence since the second half of 1950s. It is second biggest manufacturing activity in Kenya after food processing industry. There are about 60 textile mills producing a total of 83 million square metres of fabrics excluding blankets and knitted goods. Capacity utilization in the industry is not uniform. It ranges from around $25 \%$ to over $75 \%$ with approximately a mean of $70 \%$ in the garment sector.

The garment industry which uses the finished products of the textile industry is an area where the country can earn valuable foreign exchange from exports at the same time utilize local inputs. The industry is organized into formal and informal sectors.

The effective demand of clothes is widespread even in the poor economies, given that the need for clothing is a prime necessity as other basic needs like food and shelter. 
The textile industry does not require large and expensive equipments as many industries would. It is labour intensive, and wastages incurred during the various processes of manufacturing raw materials is minimal compared to other industries and this partially makes the industry more environmental friendly.

The textile industry has a variety of useful linkages for industrialization if well planned. The industry has the ability to move backwards and forwards into other sectors thus creating industrial region. Given the diverse area cotton is grown, the industry has a potential for bringing up industries in rural areas. Cotton the major raw materials for textile industry can be grown in about six provinces in the country. Therefore, creating employment in various stages of textile industry, production firms, research stations, ginneries, textile mills, garment enterprises, jua kali and cottage industries and trade/services sector.

\section{Foreign Exchange Earnings:}

The unexploited export markets in the common market for Eastern and Southern Africa (COMESA) and indeed many developing countries are potential sources of foreign exchange earnings.

The government has put many policies in support of the textile industries through the sessional papers and National Government Plans (1992, 1989-93). Promoting small scale which promoted entrepreneurial culture and focus has laid the foundation for production by masses as opposed to mass production by few large scale producers.

The government in its endeavour, in promoting textile industry, has established institutions for training personnel example Kenya Textile Training Institute, Kenyatta University, Moi University and Polytechnics. This is an indication of the right work towards the right direction for development to make the 2020 industrialization a reality.

(i) Cash receipt journal, for daily listing of an incoming cash from sales collection on account and other sources,

(ii) Cash disbursements journal, for daily listing of all out going cash,

(iii) General journal, a detailed daily listing of all other (non-cash) financial transactions such as credit sales, purchase and depreciation.

(iv) General ledger, to post monthly, quarterly on individual basis all transactions from the journals.

The records can help evaluate the past and present so as to project for the future, the help to know performance of the business, the affairs of the business and the owner's affairs. Otherwise, most small business owners mix the business and personal affairs and that is one factor that contribute to their failure Kibuka (1996). According to Masscove (1983), some small businesses have no organized method of recording transactions, i.e. they have no formal accounting system. The owner of small business view accounting as a time-consuming nuisance. In addition, he says that the use of ledger less accounting system may prove expensive in the long run, and one of the primary causes of small business failure is a simple lack of accounting instruction of one kind or another. 
Therefore, in the absence of prior business experience and accounting, information can be compensated for proper planning and self knowledge through short training courses, seminars, workshops and so on.

\section{Methodology}

The target population of this study was men and women from the eighteen city council markets, with 1610 businesses. The researcher used the list from the superintendent of city council markets to compile a sampling frame. Eighty respondents were selected at random, ten from each market in the eight Nairobi divisions.

The area of study was confined to Nairobi City Council markets. This is because there were different men and women doing this type of business from different parts of the country, a fact which was likely to increase representative ness and reduce bias emanating from ethnic differences and backgrounds. Due to financial constraints and time, Nairobi was convenient for this study.

\section{Data collection methods}

This study required the use of mainly primary and secondary data which was collected through the following instrument and method.

\section{Primary data}

(i) Semi-structured questionnaire

(ii) Observation

(iii) Discussion

The Semi-structured questionnaire was used as the research instrument. The questionnaire facilitated the collection of information on the respondents, businesses and the records maintained by the entrepreneurs.

The researcher had discussions with the respondents as a means of soliciting information which the questionnaire and observation did not elicit. Discussions helped to create rapport between the respondent and the researcher, which was beneficial to the researcher, as more information was obtained.

\section{Data Analysis and Presentation}

The main objective of this study was to establish the relationship that existed between the record keeping and the performance of small businesses. The data for the study was collected in Nairobi city council markets, from both male and female entrepreneurs. All the variables considered important and hypotheses testing were addressed here.

The analysis and presentation of the results has been done by simple tables, cross-tabulation, frequencies, percentages, mean and correlation analysis. The study targeted 80 business owners, both 
male and female, on fifty percent basis. The data analysis, therefore, was based on 80 respondents, 40 men and 40 women. This was done for comparison purposes.

What emerged from the analysis is that there is a positive relationship between maintenance of accounting records and the performance of small enterprises. Also, hard work, adequate capital and management significantly influence business performance. The results of the data analysis, therefore, formed the basis for the conclusions and recommendations in the subsequent chapter.

\section{Findings}

The following tables present some of the findings of the study.

Table 1: Problems associated with record keeping

\begin{tabular}{|l|l|l|l|}
\hline \multirow{2}{*}{ Problem } & \multicolumn{2}{|c|}{ Frequency } & \multirow{2}{*}{ Total } \\
\cline { 2 - 3 } & Male & Female & \\
\hline Time consuming & $27(68 \%)$ & $17(43 \%)$ & $44(55 \%)$ \\
\hline Accountants expensive & $3(8 \%)$ & $2(5 \%)$ & $5(6 \%)$ \\
\hline Usefulness not seen & $3(8 \%)$ & $2(5 \%)$ & $5(6 \%)$ \\
\hline Accounts Difficult & $1(3 \%)$ & $1(3 \%)$ & $2(3 \%)$ \\
\hline
\end{tabular}

\section{Source: Field data}

The table above shows that $55 \%$ of the respondents cited too much time required in record keeping as the main reason for which they do not keep records. Whereas the males $(68 \%)$ entrepreneurs cited this problem, $43 \%$ of their female counterparts cited this problem. The other problems were not seen to be significant in record keeping.

Most of the small business owners do not understand the importance of record keeping. They are involved in day to day operation of the business, without setting aside time for recording daily transaction.

Table 2: Respondents who kept records:

\begin{tabular}{|l|l|l|l|}
\hline \multirow{2}{*}{ Records } & \multicolumn{2}{|c|}{ Frequency } & Total \\
\cline { 2 - 4 } & Male & Female & \\
\hline Kept record & $28(70 \%)$ & $31(77 \%)$ & $59(74 \%)$ \\
\hline No record & $12(30 \%)$ & $9(23 \%)$ & $21(26 \%)$ \\
\hline Total & 40 & 80 & $(100)$ \\
\hline
\end{tabular}




\section{Source: Field data}

The above table shows that $74 \%$ of the respondents kept records and $26 \%$ did not keep records. Out of these respondents, $77 \%$ were female and $70 \%$ male. This shows that female entrepreneurs were more interested in knowing how their businesses were performing. This is in line with what Kibuka (1996) says, He says, in order to assess performance of a business from time to time, accounting framework endeavors to provide this.

Table 3: Records kept by the respondents

\begin{tabular}{|l|l|l|l|}
\hline \multirow{2}{*}{ Records } & \multicolumn{2}{|c|}{ Frequency } & \multirow{2}{*}{ Total } \\
\cline { 2 - 4 } & Male & Female & \\
\hline Cash book & $4(10 \%)$ & $2(5 \%)$ & $6(8 \%)$ \\
\hline Sale book & $4(10 \%)$ & $4(5 \%)$ & $8(10 \%)$ \\
\hline Purchase book & $3(8 \%)$ & - & $3(4 \%)$ \\
\hline Invoice & $2(5 \%)$ & $2(5 \%)$ & $4(5 \%)$ \\
\hline Receipts & $28(70 \%)$ & $32(80 \%)$ & $60(75 \%)$ \\
\hline Note book & $31(78 \%)$ & $32(80 \%)$ & $63(79 \%)$ \\
\hline
\end{tabular}

Source: Field data

Most (79\%) of the business owners maintained Notebooks (registers) and $75 \%$ of the respondents maintained receipt book. There were very few respondents who maintained the cashbook, $8 \%$, sales book, $10 \%$, purchase book, $4 \%$ and the invoice, $5 \%$. This shows that most businessmen do not know the importance of the books required in business.

Table 4: Information extracted from the records

\begin{tabular}{|l|l|l|l|}
\hline \multirow{2}{*}{ Purpose } & \multicolumn{2}{|c|}{ Frequency } & Total \\
\cline { 2 - 4 } & Male & Female & \\
\hline Planning & $23(58 \%)$ & $33(83 \%)$ & $56(70 \%)$ \\
\hline Decision Making & $11(28 \%)$ & $7(23 \%)$ & $18(23 \%)$ \\
\hline Other & $2(5 \%)$ & $1(3 \%)$ & $3(4 \%)$ \\
\hline
\end{tabular}


The table shows that most $(70 \%)$ of the respondents used the information from their records for planning. Females were $59 \%$ and males were $41 \%$. For decision making, $23 \%$ of which $61 \%$ were male and $39 \%$ were female. $4 \%$ of the respondents used the information for cash flow, and loan requirement. However, there were some respondents who used the information for both planning and decision making. Although most (74\%) of the respondents kept records and extracted information for planning and decision making, the qualities of relevance, reliability, comparability and consistency were not fully met. This shows that most of small business owners are not committed to their business.

Table 5: Records vs. Ownership

\begin{tabular}{|c|c|c|c|c|}
\hline Records & Individua & & Partnersl & \\
\hline & Male & Female & Male & Female \\
\hline Yes & $26(68 \%)$ & $27(75 \%)$ & $2(100 \%)$ & $4(100 \%)$ \\
\hline No & $12(32 \%)$ & $9(25 \%)$ & & \\
\hline Total & 38 & 36 & 2 & 4 \\
\hline
\end{tabular}

\section{Source: Field data}

The table above shows that $100 \%$ partnership businesses maintained records. $72 \%$ of the individually owned business maintained records. More female (75\%) owned businesses maintained records than the male $(68 \%)$ owned businesses. This may be explained from the fact that partnership businesses need more accountability because people don't trust one another; the records are better placed to show the position of the business. $66 \%$ of the partnership business was owned by female entrepreneurs. This shows that partnership businesses keep records to know the direction their businesses are moving. Mieske (1989) says that to be able to know, monitor and control the business, there is need to keep records to understand how money comes in and how it is spent.

\section{Conclusions}

From the findings and discussions, the following conclusions emerge:

The Tailoring and dressmaking business in Nairobi was dominated by female entrepreneurs. $85 \%$ of the business was owned and run by females, and they make ladies' clothes. They also performed slightly better than their male counterparts. Their mean assets were worth Ksh.112 500 while that for the male entrepreneurs were Kshs. 100, 000. 
Although $97 \%$ of the respondents said that records were useful in business, only $74 \%$ maintained records. The importance of records did not seem to be clear to them. Also, the most popular record kept by the entrepreneurs was the notebook, which $90 \%$ of them assumed to be the cash book. They used the information in this book to prepare (income and expenditure account) profit and loss account. However, few kept the cash books, invoices, receipts together with the registers. The majority kept the receipt books. This shows that they were more interested in the immediate cash and not the future of their business.

From the study, these factors emerged as having influence in business performance; hard work (75\%), adequate capital (61\%), management (56\%) and others (which included luck, marketing and corporation) $10 \%$. The former was considered as the main factor for business performance. The following factors were considered as influencing record keeping: level of education, ownership, training growth (number of employees) and business age. The higher the level of education, the greater the need for management. Also, those trained in business management kept records. The ownership of business, especially partnership, called for records because of lack of trust.

A lot of time was needed to prepare and maintain the records, hence, the poor records kept by entrepreneurs. Also, professional fees were too high for those who wished to put their records straight. There is need, therefore, to come up with simple and straight forward systems, which any common person can understand and, of course, that which will capture all the necessary information for the evaluation of profit and loss accounts. Therefore, a comprehensive record, which at a glance can give all the details (simple), is recommended.

It can be concluded that most respondents kept records for the purpose of computing profit and loss account. Although the records kept were not in strict sense accounting records, with note books and receipts as the main records. This shows that they were interested with immediate cash.

It can also be concluded that education, training and nature of ownership were the main factors that showed positive relationship to records. Some business owners do not keep records because they perceive their businesses to be too small to be managed with the help of records. That is to say, small business owners who do not keep records feel that they are capable of correctly computing revenue and expenditure from memory.

\section{Recommendations}

The issue of finance should be addressed to assist the small businesses. Nearly all lending in Kenya is security based and most loans, especially to small enterprises are not given on the basis of potential cash flow to be generated by the loans. Banks insists on tangible collaterals as security for loans. The government through relevant departments should abolish the issue of stringent collateral requirements by introducing credit guarantee schemes The government should allow professional institutions, NGOs to mobilize savings from the small entrepreneurs who should in turn support them. Interest rates should be reduced to attract borrowing by the small businesses.

The business owners should be encouraged to form associations which can assist them with finance. In fact the industry has the potential for expansion now that major firms have collapsed. Therefore, these entrepreneurs need support from the government, since they will create employment 
The Government and the NGOs should introduce training in business management, which has positive influence on business performance. The training should teach simple but effective record keeping. Those who have the college and university education should be encouraged to enter into business by being provided with start-up capital at low interest rates.

As for the import of cheap materials and 'mitumba', the government should intervene to ensure that importers pay tax for them, so that they can have same level of competition. The rents should be made standard for all city council markets, since some were higher than others sometimes by a difference as high as $2000 \%$. The government should intervene to stimulate the sector because it has growth potential now that most textile manufacturing firms have collapsed. All markets should be provided with electricity at lower rates.

Small-scale enterprise funding institutions tend to shy away from external sources due to the foreign Exchange risk element. To facilitate such funds from the external sources for small enterprises Development, the government and donors should undertake to accept the foreign exchange risks.

Simple accounting to be understood by all, especially those with low level of education should be trained. However, those able to understand and apply presumed complicated and ineffective systems can do so. The entrepreneurs should appreciate the importance of records, especially in securing loans, supporting fraud or theft cases or in case of admission of new partners. Entrepreneurs should be made to understand who should and why they should pay tax, because majority did not understand why, and in fact did not know who should pay tax.

\section{References}

Cromie, S. (1991). "The problem experienced by young firms.” International small business journal No. 9 April - June.

Gichira, R. \& Dickson, P. (1987). "Problems facing enterprises in Kenya." Paper presented to the Kenya Economic Association, at KICC.

Republic of Kenya. (1992). Small-scale and Jua Kali (Sessional paper No. 2).

Nairobi: Government Printers.

Republic of Kenya (1992) Industrial Transformation to the year 2020 (Sessional paper No. 2). Nairobi: Government Printers.

Government of Kenya. (1998). A diagnostic Study on Cotton Ginning and Textile Industry

Development. Ministry of Industrial Development and Ministry of Planning and National Development. (by Africa Development and Economic Consultant Ltd.)

Kibuka, G .(1996). Going into business. Nairobi: Project finance data centre and cons.

Kuehl, C.R \& P. A. Lambing (1990). Small Business Planning and Management. USA, The Dryden Press. 
Maalu, K. J. (1990). "Factors influencing record keeping in small scale enterprises", unpublished, M.B.A, University of Nairobi.

Mascove, A. S. and Simicin, M. C. (1983). Accounting Information System Navada: Reno

Miles, D (1995). Accounting and Book keeping for small building contractor. London. 